Michael Doyon, Laval

V. Dobrobolsky, U. of T.

Garry Bloomfield, L.U.

D.A. Sklar, U. of A.

G.E. Mancell, U.B.C.

\section{5}

E.W. Robak, U.N.B.

Clement Bordeleau, Laval

A.J. Willcocks, U. of T.

J.D. Phillips, L.U.

B.L. Phillips, U. of A.

M.O. Otterloo, U.B.C.

\section{6}

Brent Evered, U.N.B.

Giles Trudel, Laval

P.L. Marshall, U. of T.

W.A. Kenney, L.U.

Dale Darrah, U. of A.

Richard S. Sommer, U.B.C.

1977

Keith Jones, U.N.B.

Mario Blanchet, Laval

Paul C. Ward, U. of T.

Paul G. Butra, L.U.

Margaret J. Hee, U. of A.

Mary Elizabeth Suttie, U.B.C.

\section{8}

Roger J.J. Roy, U.N.B.

Claude Gignac, Laval

Sandra L. Dart (Runk), U. of T.

Reino E. Pulkki, L.U.

John C. Pollack, U. of A.

Alan J. Walters, U.B.C.

\section{9}

Thomas A. Erdle, U.N.B.

Pierre Morin, Laval

Brian A. Barkley, U. of T.

Richard Watson, L.U.

Lois H. (Pelchat) Dellert, U. of A.

Robin John Dorey, U.B.C.

\section{0}

W.L. Meyer, U.N.B.

Francois Seguin, Laval

John M. Fullerton, U. of T.

James D. Sutherland, L.U.

Byron Grundberg, U. of A.

Dan Scott Price, U.B.C.

\section{1}

Michael J.J. Connors, U.N.B.

A. DuSault, Laval

L. Vanderstar, U. of T.

Peter DeGroot, L.U.

Nola Daintith, U. of A.

Heather Jane Cook, U.B.C.

\section{2}

W.R. Thornton, U.N.B.

M. Michel Villeneuve, Laval

Colin Hewitt, U. of T.
Paul Krabbe, L.U.

Terry Kristoff, U. of A.

David Waddell, U.B.C.

\section{3}

Alan L. Anderson, U.N.B.

Danielle Legault, Laval

William S. Garton, U. of T.

Robert Mitchell, L.U.

Janice M. Traynor, U. of A.

B.W. Bergstrom, U.B.C.

\section{4}

William A. Davis, U.N.B.

John McKay, Laval

Sarah Thompson, U. of T.

David Tarjan, L.U.

Nora P. Kopjar, U. of A.

Perry M. Monych, U.B.C.

\section{5}

Shelley A. Vesico, U.N.B.

Jean-Martin Lussier, Laval

Dorli M. Duffy, U. of T.

Raymond Wagner, L.U.

Laurie Onishenko, U. of A.

Laurie Kremsater, U.B.C.

\section{6}

Philippe B. LeBlanc, U.N.B.

J.F. Côté, Laval

Silvia Strobl, U. of T.

Sylvia G. Lagen, L.U.

Glenn Farrow, U. of A.

Michael Douglas Kerr, U.B.C.

1987

Robert L. Colpitts, U.N.B.

Leon Belanger, Laval

Andrew John Mayes, U. of T.
Andrea Marie McDonald, L.U.

Kim Young, U. of A.

Cindy Lee Fox, U.B.C.

1988

F.E. Oberle, U.N.B.

Julie Chagnon, Laval

Naomi Donat, U. of T.

Scott Mitchell, L.U.

R. Prins, U. of A.

R.J. Robazza, U.B.C.

1989

E.R. Wilson, U.N.B.

Jean-Pierre Jetté, Laval

Dan Kneeshaw, U. of T.

E.H. Hoffman, L.U.

Caroline Kutash, U. of A.

W. Stump, U.B.C.

1990

Roy Cumberland, U.N.B.

Guy Serry, U. of Moncton

Solange Nadeau, Laval

Chris P. McDonnell, U. of T.

T.G. Payne, L.U.

Ken Greenway, U. of A.

Jonathan Mark S. Moss, U.B.C.

1991

Darren Fillier, U.N.B.

Emanuel Sildor, U. of Moncton

Luc Fréchette, Laval

Andrew Dunlop, U. of T.

Douglas Maki, L.U.

J.R. Harris, U. of A.

Lawrence C. Chrobot, U.B.C.

\section{D.R. Redmond, Chairman} Archival Committee

\title{
ABCPF/CIF Cooperation
}

In December 1990 the executive of the Association of B.C. Professional Foresters and Canadian Institute of Forestry appointed a task force consisting of two members representing each organization. The task force was to address the need to improve cooperation, coordination and efficiency of ABCPF/CIF activities. The two organizations were particularly interested in receiving recommendations on how we could reduce duplication and improve performance at the regional (section) level. It has been apparent to those involved that many regional activities have been sporadic and ineffective. To date, efforts by the two organizations to correct this problem have been unsuccessful.

The task force reported on November 21, 1991 and recommended a radical change to the structure and mandate of both organizations. Task force members felt that a major change was the only solution to our concerns over the long term. They felt that the current structures, duties and roles of the ABCPF and CIF are an impediment to addressing important forestry and professional issues, especially at the regional and provincial level.

The executives of the ABCPF and CIF have taken the recommendations under review and met in February to determine how to proceed. We anticipate considerable discussion with members of both organizations during 1992 , leading to a new and productive partnership between the two organizations. 


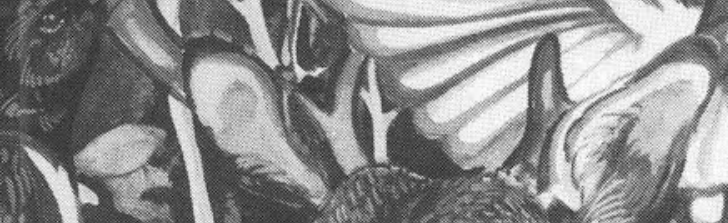

10

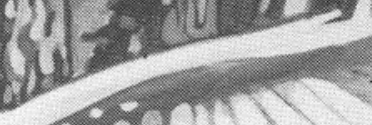

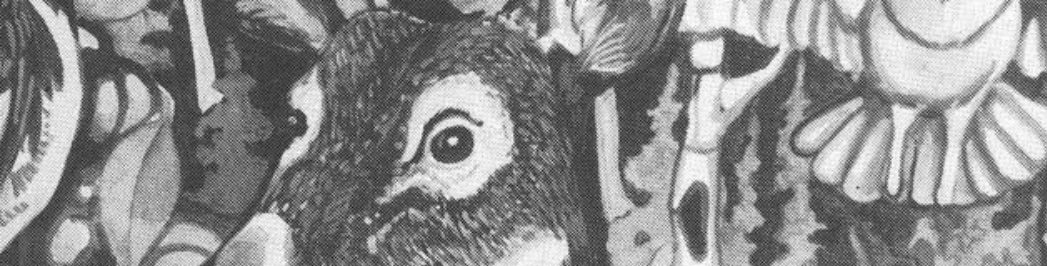

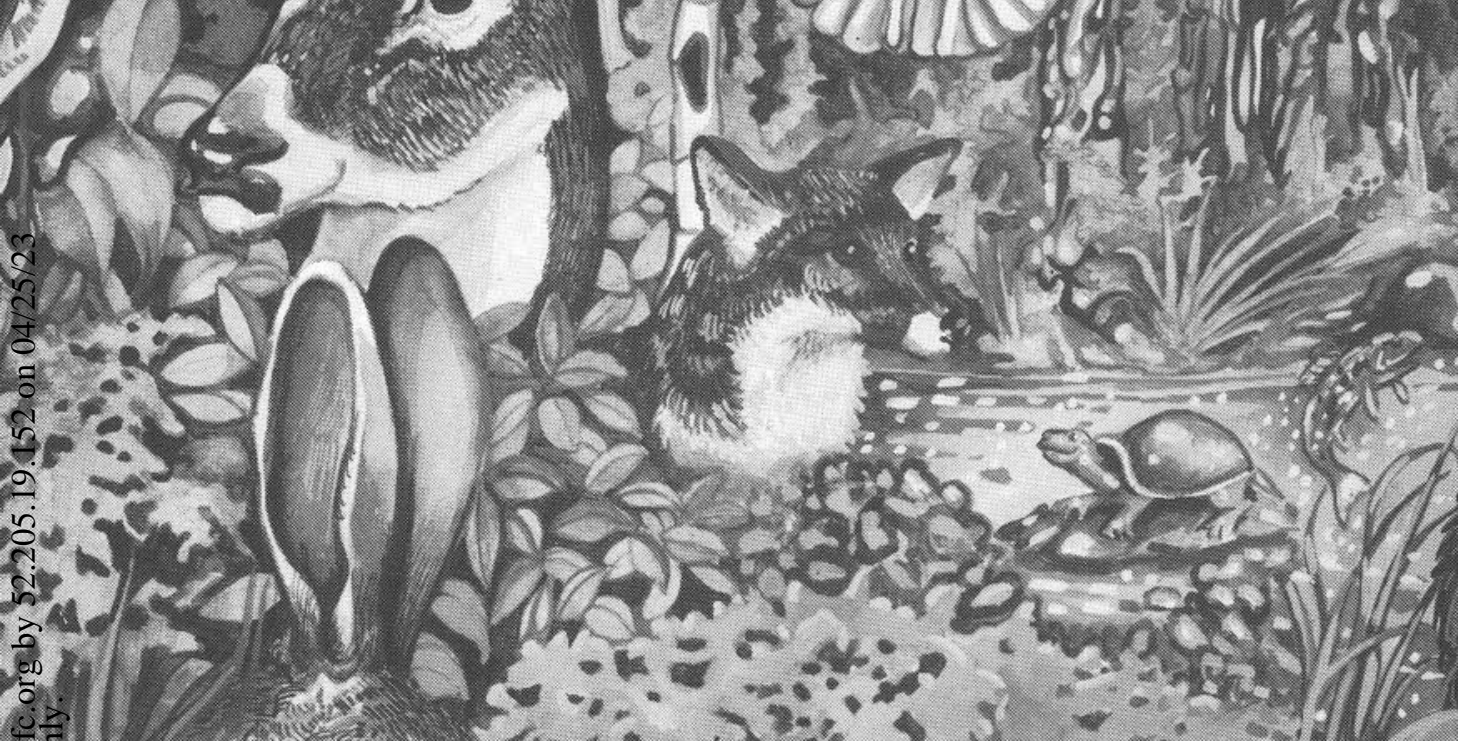

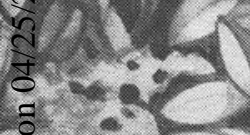

ते $-2+1=$

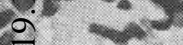

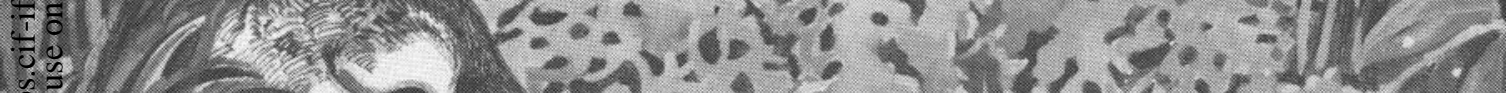

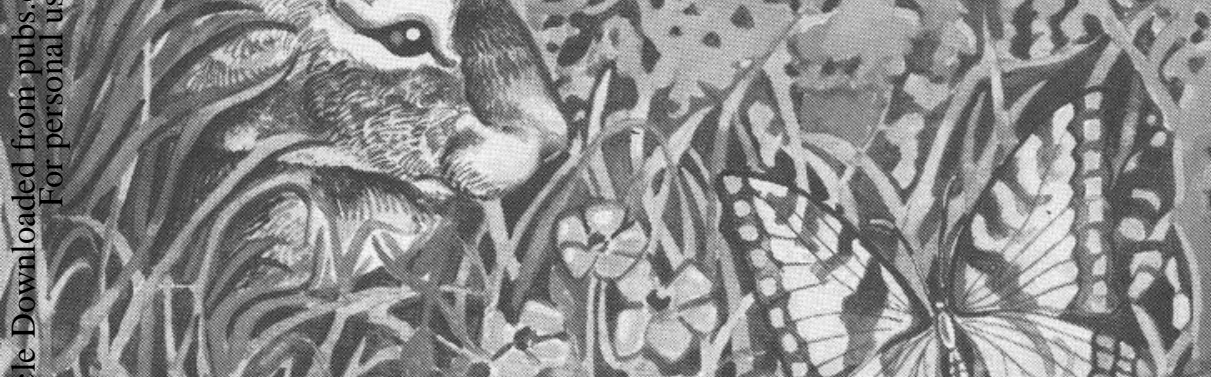

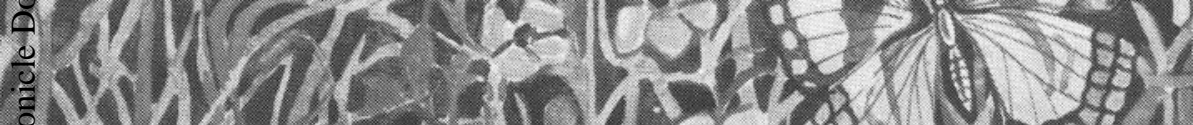

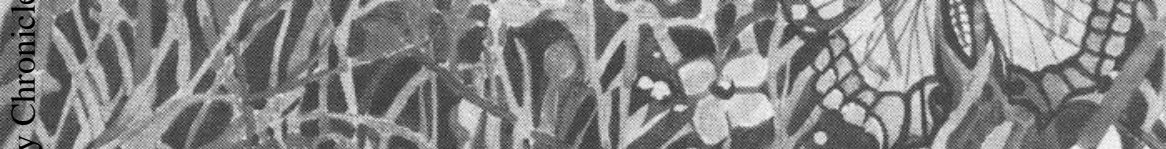

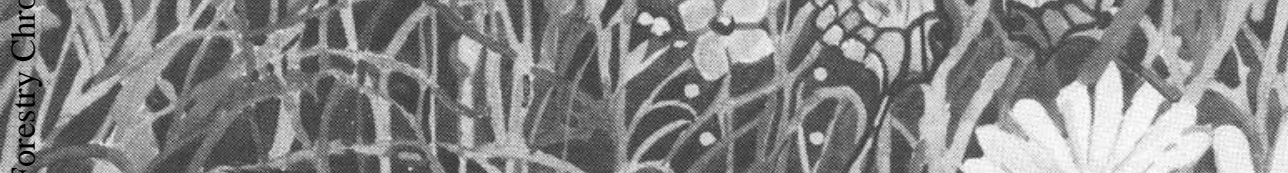

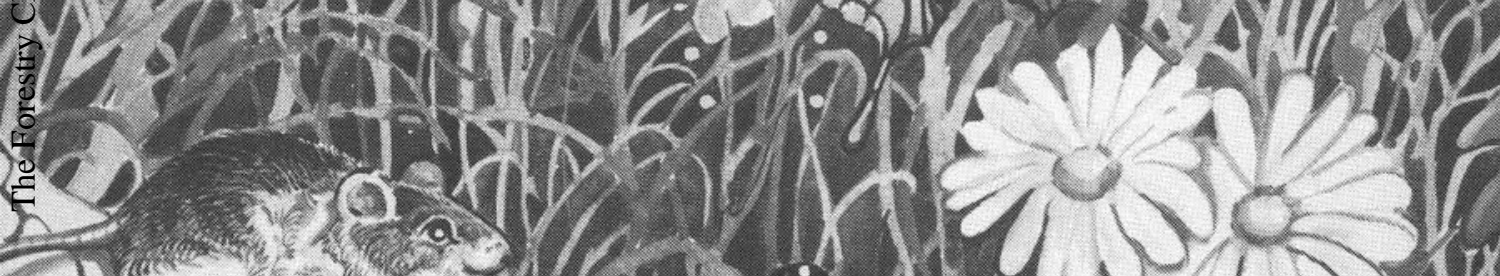

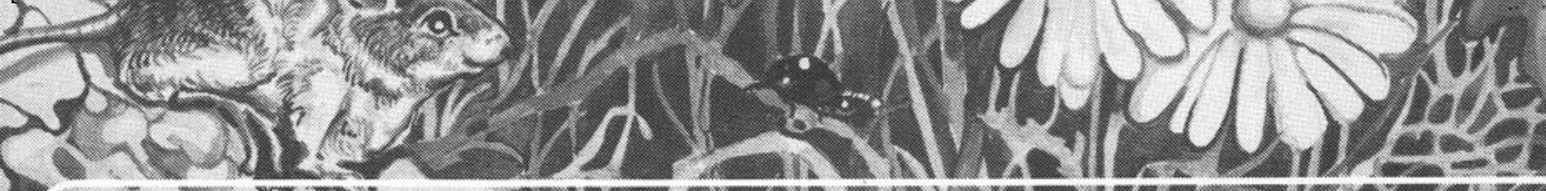

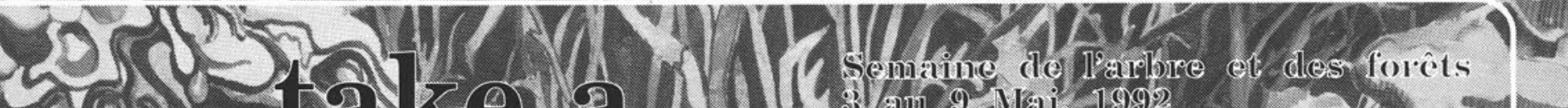

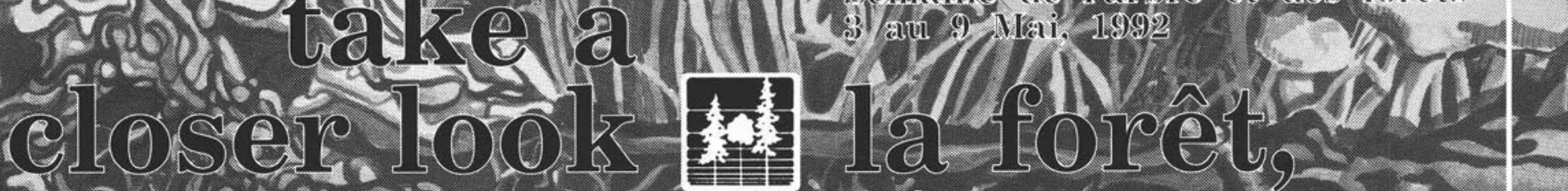
T-1, etesit-sitoer. 